\title{
TEKSTY HIERONIMA, SEDULIUSZA SZKOTA I BEDY CZCIGODNEGO W BIBLIJNYCH KODEKSACH PLOCKICH I NADMOZAŃSKICH Z XII W. PRÓBA PORÓWNANIA
}

\begin{abstract}
Archiwum Diecezji Płockiej, spadkobierca średniowiecznej biblioteki katedralnej jak również archiwum kapituły katedralnej i kolegiackiej św. Michała w Płocku oraz archiwów konsystorza płockiego i pułtuskiego zawiera wiele cennych zabytków rekopiśmiennych ${ }^{\mathrm{I}}$. Z kodeksów biblijnych związanych z Płockiem do naszych czasów zachował się słynny Złoty Kodeks Puttuski pochodzący z XI w., a przechowywany obecnie w Muzeum xx. Czaroryskich w Krakowie, a także kilka kodeksów z XII w. Do tej ostatniej grupy należy Biblia Płocka, Ewangeliarz księżnej Anastazji, Perykopy Ewangeliczne, które zawierają fragmenty Ewangelii przeznaczone do celebracji liturgicznych na różne dni roku liturgicznego, a także Ewangelia Marka z glossami Walafrida Strabona i Anzelma z Laon ${ }^{2}$. W dotychczasowych badaniach przypuszczano, że wszystkie te kodeksy zostały przywiezione do Płocka w czasach rządów diecezją biskupa Aleksandra z Malonne (II29-II56) lub Wernera (II56-II70) z kraju Mozy albo zostały sporządzone w lokalnym skryptorium w drugiej połowie XII w. ${ }^{3}$ Nie ulega wątpliwości, że za czasów biskupa Aleksandra z Malonne płockie środowisko kościelne przeżywa ogromny renesans. Za jego rządów docierają do Płocka nie tylko kodeksy biblijne czy księgi liturgiczne, ale też zapewne niektóre z nich są przepisywane na miejscu na potrzeby katedry i powstających nowych kościołów grodowych ${ }^{4}$. Wiemy, że to właśnie biskup Aleksander w II44 r. konsekruje wybudowaną przez siebie z kamienia romańską katedrę w Płocku na Wzgórzu Tumskim i zamawia dla niej odlane z brązu w Magdeburgu
\end{abstract}

\footnotetext{
Por. M. Bershon, Księgozbiór katedralny płocki, Warszawa 1899; A. Vetulani, Średniowieczne rękopisy Płockiej Biblioteki Katedralnej, „Roczniki Biblioteczne”, 7/1963, z. 3-4, s. 329; R. Knapiński, Nieznana odyseja płockich zabytków, „Roczniki Humanistyczne”, 41/1993, z. 4, s. 41-59; W. Graczyk, Biblioteka katedralna Płocka od średniowiecza do nowożytności, w: tenże (red.), Biblioteka Wyższego Seminarium Duchownego w Płocku, Płock 2003, s. 7-71; W. Graczyk-J.M. Marszalska, Księgi rękopiśmienne i stare druki w zbiorach Biblioteki Wyższego Seminarium Duchownego w Płocku. Z dziejów kultury bibliotek kościelnych w dawnych wiekach, Kraków 2010, s. 25-36.

2 Por. D. Majewski, Zasób Archiwum Diecezjalnego w Płocku, w: Biblioteka Wyższego Seminarium Duchownego w Plocku, s. 155-170.

3 Por. W. Graczyk-J. M. Marszalska, dz. cyt., s. 88.

4 Por. Cz. Deptuła, Krag kościelny płocki w połowie XII wieku, „Roczniki Humanistyczne”, 8/1960, z. 2, s. 5-122; tenże, Aleksander z Malonne, w: Encyklopedia Katolicka, t. 1, Lublin 1973, kol. 340; J. Drzymała, Działalność fundacyjna biskupa Aleksandra z Malonne, „Nasze Historie”, 3/1998, s. 37-69; M. Gębarowicz, Aleksander (zm. 1156) bp płocki, PSB t. 1 (1935) s. 65-66.
} 
słynne drzwi płockies. O ile jednak historycy sztuki od dawna już interesowali się płockimi kodeksami biblijnymi, analizując ich oprawy i zdobnictwo, o tyle nie istnieją badania porównawcze pomiędzy wersjami tekstu biblijnego płockich i nadmozańskich kodeksów. Wyczerpującą analizę zdobnictwa słynnej Biblii Płockiej przeprowadził R. Knapińskí, srebrna okładka Ewangeliarza księżnej Anastazji stała się przedmiotem badań i licznych opracowań7 , a miniatury Perykop Ewangelicznych analizował P. Skubiszewski ${ }^{8}$. W niniejszym artykule chciałbym porównać płockie kodeksy biblijne z kodeksami nadomazańskimi w nadziei, że taka analiza porównawcza dostarczy nam dodatkowych argumentów za ich nadmozańskim pochodzeniem lub pozwoli je wykluczyć. Być może tego typu analizy porównawcze pozwolą wydobyć jakieś argumenty za istnieniem w Płocku w czasach biskupa Aleksandra skryptorium, co nadal jest szeroko dyskutowane przez uczonych. Oczywiście ostateczne wnioski będzie można wysunąć dopiero po porównaniu całego zachowanego tekstu biblijnego w płockich kodeksach z nadmozańskimi i wypada mieć nadzieję, że takie badania będą nadal prowadzone. Obecne opracowanie stawia sobie bardziej skromny cel. Chcę w nim porównać teksty Listu św. Hieronima do papieża Damazego i jego wstęp do czterech Ewangelii oraz wprowadzenia Seduliusza Szkota i Bedy Czcigodnego do poszczególnych Ewangelii zachowane w Biblii Płockiej, Ewangeliarzu księżnej Anastazji i Ewangelii św. Marka $\mathrm{z}$ dwoma kodeksami pochodzącymi znad Mozy i przechowywanymi w Archiwum Biblioteki uniwersyteckiej w Liège: Ewangeliarz z Averbode i tzw. Biblia Universa. Pominięte zostaną Perykopy Ewangeliczne, gdyż kodeks nie zawiera tych tekstów, a jedynie wybrane perykopy ewangeliczne na cały rok liturgiczny.

Zanim przejdziemy do analizy porównawczej wspomnianych tekstów, przypomnijmy krótko najważniejsze wnioski dotychczasowych badań nad nimi. Przyjmuje się, że Biblia Płocka powstała w drugim ćwierćwieczu w jednym ze skryptoriów mozańskich w Leodium, Gemblaux lub samym Malonne9 . Ponieważ w Biblii znajdują się dwie zapiski o cudach, które miały miejsce w katedrze płockiej w II48 r..$^{10}$, przypuszcza się, że znajdowała się ona

\footnotetext{
5 Por. R. Knapiński, Credo Apostolorum w romańskich Drzwiach Płockich, Płock 1992; tenże, Porta Fidei Brama wiary. Romańskie Drzwi Płockie w Nowogrodzie Wielkim, Płock 2012; tenże, Uniwersalny charakter sztuki polskiej na przykładzie diecezji płockiej w czasach biskupa Aleksandra z Malonne (1129-1156), w: Fundamenty średniowiecznej Europy, red. Ż. Sztylc, D. Zagórski, A. Radzimiński, R. Biskup, Pelplin 2013, s. 285-296.

6 Por. R. Knapiński, Iluminacje romańskiej Biblii Płockiej, Lublin 1993.

7 Por. T. Mroczko, Czerwińsk romański, Warszawa 1972, s. 47-52; taże, Polska sztuka przedromańska i romańska, Warszawa 1988, s. 55nn; B. Paszkiewicz, O matce Lestka Bolesławica i poczatkach mennictwa mazowieckiego, „Przegląd Historyczny”, 92/2001, s. 1-14; K. Askanaz, O niektórych zabytkach rzemiosła artystycznego epoki romańskiej w Płocku, „Notatki Płockie”, 13/1968, s. 28-33; tenże, Srebrna okładka Ewangeliarza księżnej Anastazji, „Notatki Płockie”, 34/1989, s. 7-18.

8 Por. P. Skubiszewski, La décoration des manuscrits Płock 140 et Gniezno 110 Saint-Laurent de Liège et la Pologne, w: Clio et son Regard. Mélanges offerts à Jacques Stiennon à l'accasion de ses vingt-cinq ans d'enseignement à l'Université de Liège, ed. R. Lejeune - J. Deckers, Liège 1982, s. 615-637.

9 Por. Wł. Semkowicz, Paleografia łacińska, Kraków 2011, s. 293-295; St. Sawicka, Les Principaux manuscrits à peintures de la Bibliothèque Nationale de Varsovie, du Château Royal e des Bibliothèques: Des Zamoyski àVarsovie, du Seminaire de Plock ed du Chapître de Gniezno, „,Bulletin de a Société Francias de reproduction des Manuscrits à Peintures", 19/1938, s. 234n; R. Knapiński, Biblia Płocka. Wiedza o rękopisie w świetle dotychczasowych badań, „Studia Płockie”, 18/1990, s. 237-255; tenże, Iluminacje romańskiej Biblii Płockiej, Lublin 1993, s. 26.

10 Por. Z. Kozłowska-Budkowa, Płockie zapiski z 1148 r., „Roczniki Humanistyczne”, 44/1930, s. $341-348$. D. Brzeziński-B. Leszkiewicz, Zapiski liturgiczne w kodeksie Biblii Płockiej z XII wieku. Studium źródłoznawcze i edycja tekstu, Płock 2005, jak sami zaznaczają na s. 6 dołączyli edycję Z. Kozłowskiej-Budkowej nie odczytując
} 
w Płocku przed tą datą, być może już podczas konsekracji nowej katedry w II44 r. Zapiski te, a także wzmianka o kustoszu Azonie i scholarzu Zachariaszu, zdaniem niektórych badaczy dowodzą, że w Płocku w tym czasie działało skryptorium oraz szkoła przykatedralna. Stąd też przypuszcza się, że Biblia powstała w Płocku w lokalnym skryptorium albo przynajmniej tutaj była iluminowana przez benedyktynów przybyłych do Płocka znad Mozy ${ }^{\mathrm{II}}$. Przeciwnicy takiej hipotezy podkreślają, że notatki zostały zapisane dosyć prymitywnym stylem pisma, a karta je zawierająca została doklejona i wcale nie są dowodem na istnienie profesjonalnego skryptorium w Płocku w tym czasie, podczas gdy Biblia zostałaby przywieziona z zagranicy, najprawdopodobniej właśnie z kraju Mozy, na miejscu zaś kodeks zostałby iluminowany i dopisano by niektóre dodatki ${ }^{12}$. R. Knapiński, który jako jedyny przeanalizował Biblię zarówno od strony kodykologicznej, jak też zdobnictwa doszedł do jeszcze innego wniosku: zawiera ona dwa rodzaje miniatur, profesjonalnie wykonane w kraju Mozy i wykonane w sposób dosyć prosty dodatki na miejscu w Płocku. Jego zdaniem cały tekst biblijny, znaczna część inicjałów i niektóre miniatury powstałyby przed sprowadzeniem kodeksu do Płocka, a na miejscu dokończono by jedynie iluminowanie kart i w małym lokalnym skryptorium dodano teksty takie jak słynne zapiski o cudach, opis wielkopiątkowej liturgii katedralnej i komentarz Augustyna oraz niektóre miniatury ${ }^{13}$. Taka hipoteza zakłada, że istniało w połowie XII w. w Płocku jakieś skryptorium, choć oczywiście nie tak profesjonalne jak na zachodzie ówczesnej Europy. W każdym razie tematyka istnienia płockiego skryptorium pozostaje nadal otwarta.

Ewangeliarz księżnej Anastazji niektórzy badacze łączą z biskupem Aleksandrem ${ }^{\mathrm{I4}}$, inni natomiast przypuszczają, że został on przywieziony do Płocka przez biskupa Wernera podczas jego podróży w II65-66 roku na dwór Fryderyka Barbarossy'5. Anastazją według Długosza miała być poślubiona przez Bolesława Kędzierzawego córka księcia nowogrodzkiego Wsiewłoda, zwana po słowiańsku Wierzchosławą, która zmarła w II58 r. (a na pewno po II48 r.), i to właśnie z tej okazji Ewangeliarz zostałby ufundowany jako wotum za zbawienie jej duszy i podarowany klasztorowi kanoników regularnych w Czerwińsku. Trzecim kodeksem jest Ewangelia według św. Marka z komentarzami. A. Birkenmajer datuje okładki

na nowo tekstu. Nowe odczytanie zapisków wraz z nowym ich tłumaczeniem na j. polski - zob. L. Misiarczyk, Zapiski o cudach z 1148 roku w Biblii Ptockiej, ABMK 104 (2015) s. 189-201.

11 Por. F. Kopera, Dzieje malarstwa w Polsce. Średniowieczne malarstwo w Polsce, t. 1, Kraków 1925, s. 18; M. Bershon, Księgozbiór katedralny płocki, Warszawa 1899; A. Vetulani, Średniowieczne rękopisy Płockiej Biblioteki Katedralnej, „Roczniki Biblioteczne”, 7/1963, z. 3-4, s. 329; W. Góralski, Kapituła katedralna w Płocku XII-XVI w. Z dziejów organizacji prawnej kapitut polskich, Płock 1979.

12 Por. Z. Kozłowska-Budkowa, Ptockie zapiski z 1148 r., „Roczniki Humanistyczne”, 44/1930, s. 341-348; St. Sawicka, Les Principaux manuscrits à peintures de la Bibliothèque Nationale de Varsovie, du Château Royal e des Bibliothèques: Des Zamoyski àVarsovie, du Seminaire de Plock ed du Chapître de Gniezno, „,Bulletin de a Société Francias de reproduction des Manuscrits à Peintures", 19/1938, s. 234n., M. Morelowski, Związki artystyczne i kulturalne pomiędzy Polska a krajami położonymi nad Moza i Sekwana, Wrocław 1963; Wł. Semkowicz, Paleografia łacińska, s. 293-295; M. Walicki, Wyposażenie artystyczne dworu i kościoła, w: tenże (red.), Sztuka polska przedromańska i romańska do schyłku XIII wieku, t. 1, Warszawa 1971, s. 249-303.

13 Por. R. Knapiński, Biblia Płocka. Wiedza o rękopisie w świetle dotychczasowych badań, „Studia Płockie”, 18/1990, s. 237-255; tenże, Iluminacje romańskiej Biblii Płockiej, Lublin 1993, s. 203-211.

14 Por. Wł. Semkowicz, dz. cyt., s. 294.

15 Por. T. Mroczko, Czerwińsk romański, s. 47-52. 
tego kodeksu na ok. II50 r., a za nim przyjmują taką datację Nowowiejski i Vetulani ${ }^{16}$. Choć przyjmuje się, że kodeks pochodzi z pierwszej połowy XII w. z terenu północnej Francji ${ }^{17}$, takie przypuszczenia nie zostały poparte żadnymi solidnymi badaniami paleograficznymi lub kodykologicznymi, które są absolutnie konieczne, gdyż dukt pisma tekstu Ewangelii nie jest minuskułą karolińską typową dla pierwszej połowy XII w., ale uncjałą, co wskazywałoby na jego pochodzenie z końca XII lub nawet początku XIII w. Nie rozstrzygnięte pozostaje nadal miejsce pochodzenia kodeksu. Widzimy więc, że wnioski z badań nad biblijnymi kodeksami płockimi nie zostały poprzedzone żadnymi szczegółowymi analizami kodykologicznymi i paleograficznymi, a oparte jedynie na ogólnej wiedzy historycznej. Różni badacze powtarzają zaproponowane przez innych ogólne wnioski, nie wnosząc nic nowego do dyskusji. Płockie kodeksy biblijne z XII w. nadal czekają na takie analizy, bez których nie posunie się badań nad nimi do przodu.

Jeśli zaś chodzi o kodeksy nadmozańskie, to Ewangeliarz z Averbode, oznaczony numerem 363 w zbiorze rękopisów Biblioteki Uniwersyteckiej w Liège, posiada wymiary 277 na 192 milimetry, został spisany minuskułą romańską i datowany jest na lata II50-II75. Powstał i był przechowywany w istniejącym do dzisiaj opactwie premonstratensów w Averbode powstałym W ok. II30 r. ${ }^{18}$ Natomiast tzw. Biblia Universa w dwóch księgach oznaczonych numerami 224 i 225 powstałaby w opactwie św. Trudona, na co wyraźnie wskazuje zapis z XV w.: Iste liber pertinet venerabili monasterio Sancti Trudonis. Pierwszy tom zawiera księgi Starego Testamentu od księgi Rodzaju do Proroków mniejszych i powstałby ok. roku II20, natomiast tom drugi zawiera pozostałe księgi Starego Testamentu wraz z całym Nowym Testamentem i zostały spisany w roku II67. W przypadku Biblia Universa jesteśmy w bardzo dobrej sytuacji, gdyż kodeks zawiera notkę historyczną z dokładną jej datacją. Na pierwszej karcie verso pierwszego tomu czytamy: Scriptus est hic liber sub Rudolpho abbate sub annum MCXVIII ut ex fine colligitur, a także na pierwszej karcie verso drugiego tomu: Scriptus sub Rodulpho abbate ut ex fine tomi praecedentis colligitur, sub anno MCXVIII. Kodeks ma wymiary 405 na 327 milimetrów, spisany został przez wprawnego kopistę minuskułą romańską. Obydwa kodeksy zawierają miniatury typowe dla sztuki mozańskiej z XII w. ${ }^{19}$

Układ tekstów wprowadzeń św. Hieronima, Seduliusza Szkota i Bedy Czcigodnego jest we wszystkich wspomnianych kodeksach bardzo podobny, choć kodeksy płockie są uboższe i nie zawierają wszystkich tekstów. Najbardziej kompletny jest Ewangeliarz z Averbode, który zawiera następujące tytuły: Beatissimo pape Damaso Iheronim[us], Prologus quattuor ev[an] gel[iorum], Eusebi[us] Carpiano Fr[atr]i in D[omi]no Sal[ute], Iheronimus Damaso pap[a]e, Incipit Argument[um] s[e]c[un]d[u]m Mathe[um], Explicit Argumentum, Incipit Breviarium

\footnotetext{
16 Por. A. Birkenmajer, Die nächsten Aufgaben dei der Erforschung der Früchgeschichte des gepressten Ldereinbandes im Christlichen Europa, ,Jahrbuch der Einbandkunst“, 1/1927, s. 13n; A.J. Nowowiejski, Płock. Monografia historyczna, Płock 1930, s. 450; A. Vetulani, Średniowieczne rękopisy płockiej biblioteki katedralnej, s. 415.

17 Por. W. Graczyk-J.M. Marszalska, Księgi rękopiśmienne i stare druki w zbiorach Biblioteki Wyższego Seminarium Duchownego w Płocku. Z dziejów kultury bibliotek kościelnych w dawnych wiekach, s. 84.

18 Por. W. Petke, Provenienz und Datierung des Evangeliars von Averbode, Scriptorium 33 (1979) s. 206-218.

19 Por. J. Stiennon, Documents inédits sur l'organisation domaniale de l'abbaye de Saint-Trond au XIIe siècle, Bulletin de la Commission royale d'histoire, 114 (1949) s. 172-173; tenże, Du lectionnaire de Saint-Trond aux Evangiles d'Averbode: contribution à l'étude de la miniature mosane au XIIe siècle, w: Scriptorium, Gand 1953, s. 42-43; M. R. Lapière, La lettre ornée dans les manuscrits mosans d'origine bénédictine (XI'-XII ${ }^{\mathrm{e}}$ siècles), Liège 1981, s. 202- 204, 206-215.
} 
Eiusde[m], następnie mamy kanony Euzebiusza i tekst Ewangelii według św. Mateusza, Explicit liber $\mathrm{s}[\mathrm{an}] \mathrm{c}[\mathrm{t}] \mathrm{i}$ evangelii $\mathrm{s}[\mathrm{e}] \mathrm{c}[\mathrm{un}] \mathrm{d}[\mathrm{u}] \mathrm{m}$ Mathe[um], Incipit Prolog[us] in Marco, Explicit argumentum, Incipit breviari[um], tekst Ewangelii według św. Marka, Explicit ev[an] geli[um] secundum Marcum, brak tytułu, Explicit argumentu[m] secundum Lucam, Incipit capitula, tekst Ewangelii według św. Łukasza, Explicit Evangelium secundum Lucam, Incipit Prolog[us] s[e]c[un]d[u]m Iohannem, Explicit Prolog[us] s[e]c[un]d[u]m Iohannem, Incipit Breviarium s[e]c[un]d[u]m Iohannem, tekst Ewangelii według św. Jana.

W Biblia Universa znajdujemy takie tytuły: Explicit prefatio hieronimi pr[es]b[ite]ri in ev[an]g[e]1[i]o incipit prim[um], który zawiera tekst Euzebiusza do Karpianusa, prefatio odpowiada tekstowi Beatissimo pape Damaso Iheronim[us], w Ewangeliarzu z Averbode Incip[it] P[re]phatio S[an]c[t]i Iheronimi Pr[es]b[iter]i In Libro Quattuor Evvangelior[um]. beatissimo papa damaso z Biblii Płockiej, item argvmentvm tożsame z tekstem Prologus quattuor ev[an]gel[iorum], natomiast tytuł $\mathrm{P}[\mathrm{re}]$ phatio ev[an]g[e]lii s[e]c[un]d[u]m mathev[m] zapowiada tekst w innych źródłach oznaczony jako Argument[um] s[e]c[un]d[u]m Mathe[um], explicivnt pr[a]efationes, brakuje zupełnie kanonów Euzebiusza i spisu treści, a mamy inny tekst dotyczący klasztoru S. Trudonis i potem tekst Ewangelii Mateusza, Incipit Prolog[us] $\mathrm{s}[\mathrm{e}] \mathrm{c}[\mathrm{un}] \mathrm{d}[\mathrm{u}] \mathrm{m}$ Marcvm, epliciti prefatio, incipivnt capitula, eplicivnt capitula, tekst Ewangelii według św. Marka, Explicit ev[an]geli[um] secundum Marcum, incipit Prolog[us] in ev[an] $\mathrm{g}[\mathrm{e}] \mathrm{lio} \mathrm{s}[\mathrm{e}] \mathrm{c}[\mathrm{un}] \mathrm{d}[\mathrm{u}] \mathrm{m}$ lucam, explicit prologus, sequuntur capitvla, explicivnt capitula, tekst Ewangelii według św. Łukasza, Explicit Evangelium secundum Lucam, p[re]f[atio] ev[an] $\mathrm{g}[\mathrm{e}] \mathrm{lii} \mathrm{s}[\mathrm{e}] \mathrm{c}[\mathrm{un}] \mathrm{d}[\mathrm{u}] \mathrm{m}$ iohannem, explicit praefatio, incipiunt capitvla ev[an]g[e]lii s[e]c[un] $\mathrm{d}[\mathrm{u}] \mathrm{m}$ iohannem, explicivnt capitula, tekst Ewangelii według św. Jana.

W Biblii Płockiej znajdujemy tylko następujące tytuły: Incip[it] P[re]phatio S[an]c[t]i Iheronimi $\operatorname{Pr}[\mathrm{es}] \mathrm{b}$ [iter]i In Libro Quattuor Evvangelior[um]. beatissimo papa damaso, co treściowo odpowiada listowi Hieronima pt. Beatissimo pape Damaso Iheronim[us], explicit $\mathrm{p}$ [re]phatio, incip[it] prolog[us] in iiiior evvangeliorum dokładnie tak w Ewangeliarzu z Averbode, brakuje natomiast Listu Euzebiusza do Karpiana i trzeciego tekstu Hieronima, następnie mamy explicit prolog[us], incip[it] argument[um] s[e]c[un]d[u]m Mathe[u]m, Explic[it] Argum[en]tv[m], Incip[it] Breviariu[m] Ei[us]de[m], dalej są kanony Euzebiusza i tekst Ewangelii według św. Mateusza, Explic[it] Ev[an]g[e]liu[m] s[ecundum] Math[eu]m, Incip[it] Prolog[us] In Ev[an]g[e]lio S[ecundum] Marcu[m], Explic[it] Prolog[us], incipiunt cap[i]t[ul] a, expliciunt cap[i]t[ul]a, tekst Ewangelii według św. Marka, Incipit Prolog[us] s[ancti] ev[an] $\mathrm{g}[\mathrm{e}] \mathrm{lii}$ s[ecundum] lucam, explicit $\mathrm{p}[\mathrm{ro}] \operatorname{logus}$, incipiunt cap[i]t[ul]a, tekst Ewangelii według św. Łukasza, Incip[it] p[rep]h[ati]o in ev[an]g[e]lio s[ecundum] iohanne[m], tekst Ewangelii według św. Jana.

W Ewangeliarzu Anastazji mamy Incip[it] P[re]phatio S[an]c[t]i Iheronimi Pr[es]b[iter] i In Libro Quattuor Evvangelior[um]. Beatissimo pape Damaso Iheronim[us], explicit p[re] phatio, incipit prologvs, brakuje Listu Euzebiusza do Karpiana i trzeciego tekstu Hieronima tak jak w Biblii Płockiej, następnie jest explic[it] p[ro]log[us], Incipit argumentum bez dodania, że chodzi o Mateusza, Explicit argumentum, Incipiunt capitula, następnie mamy kanony Euzebiusza i tekst Ewangelii według św. Mateusza od początku do I8,9. Brakuje dalszej części Ewangelii Mateusza, wprowadzenia jak też samego tekstu Ewangelii Marka oraz wstępu do Łukasza, zaś sam tekst Ewangelii Łukasza został zachowany tylko od 7,34 do końca Ewangelii. Na karcie 95 kodeksu znajdujemy natomiast bez jakiegokolwiek tytułu to 
samo, co w Biblii Płockiej, czyli wprowadzenie do Ewangelii Jana oraz również bez tytułu capitula i dalej tekst Ewangelii według św. Jana.

Z kolei Ewangelia Marka nie zawiera żadnego tytułu ani na początku ani na końcu wprowadzenia. Porównując wszystkie tytuły widać wyraźnie, że były one traktowane przez kopistów dosyć swobodnie i używano zamiennie: prefatio, prologus i argumentum, a także breviarium i capitula. Kodesky nadmozańskie, zwłaszcza Ewangeliarz z Averbode, są solidniej wykonane również od strony estetycznej niż płockie a także są bardziej spójne w zapisach: tam gdzie w tytule wprowadzenia jest prologus, to na zakończenie również pojawia się ten sam termin. Może to wskazywać na fakt, że kodeksy płockie powstały w mniej wyrafinowanym skryptorium lokalnym, choć spisane przez kopistów nadmozańskich.

Teksty służące porównaniu zostały odczytane z Ewangeliarza z Averobde, gdyż jest on najbardziej kompletny i w przypisach zostały zaznaczone różnice w pozostałych kodeksach.

\section{BEATISSMO PAPE DAMASO IHERONIM[US $]^{20}$}

NOVUM OPUS facere me cogis ex vetere ut post exemplaria scripturar[um] toto orbe disp[er]sa quasi quidam arbiter sedeam et quia inter se uariant qu[a]e sint illa qu[a]e cum greca consenciant $^{21}$ veritate decernam. Pius labor $s[\mathrm{ed}]$ periculosa $\mathrm{p}[\mathrm{re}] \mathrm{su}[\mathrm{m}] \mathrm{ptio} \mathrm{p}^{22}$ iudicare de $\mathrm{c}[\mathrm{a}]$ eteris ipsum ab om[n]ib[us] iudicandum senis mutare linguam et conescente[m] ${ }^{23}$ mundu[m] ad inicia ${ }^{24}$ retrahere ${ }^{25}$ paruulor[um]. Quis eni[m] doctus partier uel indoctus cu[m] in manus ${ }^{26}$ uolume assumpserit ${ }^{27}$ et $\mathrm{a}^{28}$ saliua qua[m] semel inbibit uiderit discrepare q[uo]d lectitat non statim erumpat in uocem me falsariu[m] ${ }^{29}$ me clamans ${ }^{30}$ esse sacrilegum qui audea[m] aliquid in ueterib[us] libris addere, mutare, corrigere? Aduersus quam inuidiam duplex causa me consolat[ur]: q[uo]d et tu q[ui] sum[us] $]^{31}$ sacerdos es fieri ${ }^{32}$ iubes et uerum non esse q[uo] $\mathrm{d}$ uariat etia[m] maledicor[um] testimonio comp[ro]bat[ur]. Si enim latinis exemplarib[us] fides est adhibenda, respondeant quib[us] $]^{33}$ tot $s[\mathrm{un}] \mathrm{t}$ exemplaria pene quot $\operatorname{codices}^{34}$. Sin aute[m] ueritas est querenda de plurib[us] cur non ad grecam originem reuertentes ea qu[a]

\footnotetext{
20 Biblia Płocka (= BP) ma bardziej rozbudowany tytuł: INCIPIT P[RE]PH[ATI]O S[ANCTI] IHERONIMI PR[ES]B[ITER]I IN LIBRO QUATUOR EV[AN]G[E]L[I]ORU[M]. BEATISSIMO PAPA DAMASO IHERONIM[US]; Ewangeliarz Anastazji (=EA) ma tytuł taki sam jak Biblia Płocka: INCIPIT P[RE]PH[ATI]O S[ANCTI] IHERONIMI PR[ES]B[ITER]I IN LIBRO IIII-or EV[AN]G[E]L[I]ORU[M]. BEATISSIMO PAPA DAMASO IHERONIM[US]; Biblia Universa (=BU) ma tytuł: PREFATIO II.

21 EA, BP i BU consentiant.

22 BP consumptio. Wyraźny błąd kopisty.

23 EA i BP canescentem iam.

24 BU i BP initia.

25 BP trahere.

26 EA i BP manu sua.

27 BP adsumpserit.

28 BP om.

29 BP fallalrium. Wyraźny błąd skryby, który pomylił literę $s$ z $l$.

30 EA i BP clamitans.

31 BU i BP summus.

32 EA i BP si fieri.

$33 \mathrm{EA} \mathrm{i} \mathrm{BP}+$ enim.

34 BP tot sunt pene exemplaria quot codices.
} 
e uel a uiciosis ${ }^{35}$ interp[re]tib[us] male edita uel a p[re]su[m]ptorib[us] inperitis ${ }^{36}$ emendata $\mathrm{p}$ [er]uersius uel a libraríís dormitantib[us] aut addita sunt aut mutata corrigimus? ${ }^{37}$ Neq[ue] uero ego de uetere disputo testa[m]ento quod a septuaginta ${ }^{38}$ seniorib[us] in grecam linguam uersum tercio ${ }^{39}$ gradu ad nos usq[ue] p[er]uenit. Non ${ }^{40}$ quero q[ui]d aquila q[ui]d sýmmachus sapiant, quare theodocion ${ }^{41}$ inter nouos et ueteros medius incedat; sit illa uera interp[re]tatio qua[m] ap[osto]li p[ro]bauer[un]t. De nouo nunc loquor testamento, q[uo]d grecum esse non dubium est, excepto ap[osto]lo matheo qui prim[us] in iudea euangelium xpi hebraicis litteris edidit. Hoc certe ${ }^{42}$ cum in $\mathrm{n}$ [ost]ro sermone discordat et diu[er] $\operatorname{sos}^{43}$ riuulorum tramites ducit uno, de fonte querendum ${ }^{44}$ est. Pretermitto eos codices quos a luciano et esýcio ${ }^{45}$ nuncupatos paucor[um] hominu[m] asserit peruersa contentio, quib[us] utiq[ue] nec in uetere ${ }^{46}$ instrumento ${ }^{47}$ post septuaginta ${ }^{48}$ interp[re]tes emendare qui ${ }^{49}$ licuit nec in nouo $\mathrm{p}[\mathrm{ro}]$ fuit emendasse cum multar[um] gencium ${ }^{50}$ linguis sc[ri]ptura ante translata doceat falsa esse qu[a] $\mathrm{e}^{5 \mathrm{I}}$ addita sunt. Igit[ur] $\mathrm{h}[\mathrm{a}] \mathrm{ec}^{52} \mathrm{p}$ [re]sens $\mathrm{p}[\mathrm{re}]$ fatiuncula ${ }^{53}$ pollicet[ur] quattuor tantu[m] [a] $\mathrm{eu}[\mathrm{an}] \mathrm{g}[\mathrm{e}] \mathrm{listas}$ quor[um] ordo iste est mattheus marcus lucas iohannes, codicum grecor[um] emendata ${ }^{54}$ collatione ${ }^{55} \mathrm{~s}[\mathrm{ed}]^{56}$ ueterum qu[a]e ne multu[m] ${ }^{57}$ a lectionis latin[a]e consuetudine discreparent, ita calamo imperauim[us $]^{58}$ ut his tantu[m] qu[a]e sensum uidebant[ur] mutare correctis, reliqua manere paterem[ur] ut fuerant. Canones quoq[ue] quos eusebius cesariensis epc ${ }^{59} \mathrm{al}[\mathrm{a}]$ exandrin[us] secutus ammoniu[m] in decem numeros ordinauit, sicut in greco habentur expressim[us], quo si quis de curiosis uoluerit nosse qu[a]e in eu[an]g[e]

35 BU i BP uitiosis.

6 EA i BP imperitis.

37 EA i BP ma tylko emendata corrigimus. Opuszczona jest część tekstu: peruersius uel a librariis dormitantibus aut addita sunt aut mutate obecna w Ewangeliarzu Averoboda i BU.

38 BU ma LXX.

39 BU tertio.

40 BU Nam.

41 BU i BP Theodotion.

42 EA i BP certe + quod.

43 EA in diuersos; BU uarios.

44 BU querendus.

45 BU [a]esichio.

46 BU i BP ueteri.

Błąd kopisty. EA ma testamento, co jest poprawne; BU i BP instrumento.

BU i BP mają LXX.

EA i BP quid.

BU i BP gentium.

BP quod.

BP hoc.

BP prefaciuncula.

EA emendata codicum grecorum; BP codicum grecorum emendata.

BU conlatione.

BU i BP sed et.

EA multarum.

BP temperauimus.

BU eps. 
líís uel eadem uel uicina uel sola sint, eor[um] distinctione ${ }^{60} \operatorname{cognoscat}_{\text {. Magnus siquide[m] }}{ }^{61}$ hic in $\mathrm{n}$ [ost]ris codicib[us] error inoleuit, dum q[uo]d in eade[m] re alius eu[an]g[e]lista plus dixit, in alio quia minus putauerin[t $\mathrm{t}]^{62}$ addider[un]t; uel dum ${ }^{63}$ eundem sensum alius aliter expressit, ille qui unum e quattuor p[ri]mum legerat, ad eius exempl[um] ceteros quoq[ue] estimauerit emendandos. Vnde accidit ut apud nos mixta sint om[n]ia, et in marco plura luc[a] e atq[ue] mathei, rursum in matheo iohannis et marci, et in c[a]eteris reliquor[um] qu[a]e in alíís p[ro]pria sunt inueniant[ur]. Cum itaq[ue] canones legeris qui subiecti sunt, confusionis errore sublato et similia omniu[m] scies et singulis sua qu[ae]q[ue] resititues. In canone $\mathrm{p}[\mathrm{ri}]$ mo concordant quattuor, math[eu]s marcus lucas ioh[anne]s; in s[e]c[un]do tres, math[eu]s marcus lucas, in tercio ${ }^{64}$ tres, math[eu]s lucas ioh[anne]s, in quarto ${ }^{65}$ tres, mathe[us] marcus ioh[anne]s, in q[ui]nto duo, math[eu]s lucas, in sexto duo, math[eu]s marcus, in septimo duo, math[eu]s ioh[anne]s, in octauo duo, lucas marcus; in nono duo, lucas ioh[anne]s; in decimo $\mathrm{p}[\mathrm{ro}]$ pria unsq[ui]sq[ue], qu[a]e $\mathrm{n}[\mathrm{on}]$ habent[ur] in alíís, ediderunt. Singulis uero [a]eu[an] g[e]líís ab uno incipiens usq[ue] ad fine[m] libror[um] dispar numerus increscit. Hic nigro colore $\mathrm{p}$ [re]scriptus sub se habet alium ${ }^{66}$ ex mineo ${ }^{67}$ numeru[m] discolorem, qui ad decem usq[ue] $\mathrm{p}$ [ro]cedens indicat, $\mathrm{p}$ [ri] or numerus in quo sit canone required[us]. Cum ig[itur] ap[er]to codice uerbi gr[ati]a illud siue illud capitulu[m] scire uolueris cui[us] canonis sit, statim ex subiecto numero doceberis et recurrens ad $\mathrm{p}$ [ri]ncipia in quib[us] canonu[m] est ditincta congeries, eodemq[ue] statim canone ex titulo frontis inuento, illum quem querebas numeru[m] eiusdem [a]eu[an]g[e]list[a]e qui et ipse ex insc[ri]ptione signatur inuenies, atq[ue] e uicino c[a]eteror[um] tramitib[us] inspectis, quos numeros e regione habeant adnotabis; et cum scieris, recurris ${ }^{68}$ ad uolumina singular[um] et sine mora, rep[er]itis numeris quos ante signaueras, repperies et loca in quib[us] uel eadem uel uicina dixerunt.

Opto ut in xpo ualeas et memineris mei, $\mathrm{p}[\mathrm{a}] \mathrm{p}[\mathrm{a}] \mathrm{b}[\mathrm{ea}] \mathrm{tissime}{ }^{69}$.

EXPLICIT PR[E]PHATIO.

PROLOGUS QUATUOR EV[AN]G[E]LIOR[UM] $]^{70}$

PLURES fuisse qui [a]euangelia sc[ri]pserunt et Lucas [a]eu[an]gelista testat[or $]^{71}$ dicens: q[uonia]m quide[m] multi conati sunt ordinare narration[m] reru[m] qu[a]e in nobis

60 EA distincione eorum; BP eorum distinctione.

61 EA quidem.

62 BP putauerunt.

63 EA, BP i BU cum.

64 BU tertio.

65 BP in quatuor. Błąd skryby.

66 EA altum.

67 BU i BP ex minio.

68 BP recurrens.

69 W Ewangeliarzu Averboda dodatek mniejszymi literami. W pozostałych tekst pisany jest normalnymi literami.

70 Tekst jest fragmentem z Commentariorum in Evangelium Matthei; BU ma tutaj inny tytuł: ITEM ARGUMENTUM IIII i tekst występuje po następnym. BP - INCIP[IT] PROLOG[US] IN IIII-OR EVVANGELIORUM; EA INCIPIT PROLOGUS.

71 EA testatur Lucas euangelista; BP Lucas euangelista testatur. 
complet[a] $e^{72}$ sunt sicut tradider[un]t nobis q[ui] ab inicio ${ }^{73}$ ipsi uider[un]t sermone [m] et ministrauer[un]t ei et $\mathrm{p}$ [er]seuerantia usq[ue] ad $\mathrm{p}[\mathrm{re}] \mathrm{sens}$ temp[us] monimenta ${ }^{74}$ declarant, $\mathrm{qu}[\mathrm{a}] \mathrm{e}$ a diuersis auctorib[us] edita diuersam heresium ${ }^{75}$ fuere $\mathrm{p}$ [rin]cipia ut est illud iuxta egýptios et thomam et mathiam ${ }^{76}$ et bartholome[um] dudecim ${ }^{77}$ quoqu[ae] ap[os]to[lorum] et basýlidis ${ }^{78}$ atq[uae] appellis ${ }^{79}$ ac reliquor[um $]^{80}$ quos enumerare longissim[um] est cu[m] hoc tantu[m] in $\mathrm{p}[\mathrm{re}]$ sentiar[um] necesse sit dicere, extitisse quosda[m] qui sine sp[irit]u et gra[tia] dei conati sunt magis ordinare narration $[\mathrm{m}]$ qua[m] hýstori $[\mathrm{a}]^{8 \mathrm{I}}$ texere veritate[m]. Quib[us] iure potest illud p[ro]pheticum coaptari. Ve qui p[ro]phetant de corde suo: qui ambulant post sp[iritu]m suu [m], qui dicunt: dicit d[omi]n[u]s; et d[omi]n[us] non misit eos $($ Ez 13,3$)$. De quib[us] et ${ }^{82}$ saluator in [a]eu[an]gelio ioh[ann]is loquit[ur]: Om[nes] qui ante $m e^{8_{3}}$ uener[un]t fures fuerunt ${ }^{84}$ et latrones $(\mathrm{J}$ Io,8). Qui uener[un]t, non qui missi sunt. Ipse eni[m] ait: Ueniebant et ego non mittebam ${ }^{85}$ eos (Ir I4,I4). In $^{86}$ uenientib[us] p[rae]sumptio temeritatis in $^{87}$ missis obsequiu[m] serutituis est. [A]eccl[esi]a autem qu[a]e supra petram $\mathrm{d}[\mathrm{omi}] \mathrm{ni}$ uoce fundata est, qua[m] introdux[it] rex in cubiculu[m] suu[m] et ad qua[m] $\mathrm{p}[\mathrm{er}]$ foramen descensio[n]is occulte misit manu[m] sua[m]. Similis dammul[a] ${ }^{88}$ hýnnuloq[ue ${ }^{89}$ ceruor[um] quattuor ${ }^{90}$ flumina paradýs $\mathrm{si}^{91}$ instar eructuans quattuor ${ }^{92}$ angulos et anulos habet $\mathrm{p}$ [er] quos quasi archa ${ }^{93}$ testam[en]ti et custos legis d[omi]ni lignis mobilib[us] uehitur.

Primus omniu[m] matheus est publican[us] cogonomento leui, qui [a]euangelium in iudea hebreo sermone edidit ob eor[um] uel maxime causam qui in ihm crediderant ex iudeis et nequaq[uam] legis umbra succedente ${ }^{94}[\mathrm{a}]$ euangelíi ueritate $[\mathrm{m}]$ seruabant. $\mathrm{S}[\mathrm{e}] \mathrm{c}[\mathrm{un}] \mathrm{d}[\mathrm{u}] \mathrm{s}$ marcus interpres ap[osto]li petri et alexandrine[a]e [a]ecclesi[a]e p[ri]mus ep[iscopu] $\mathrm{s}^{95}$ qui

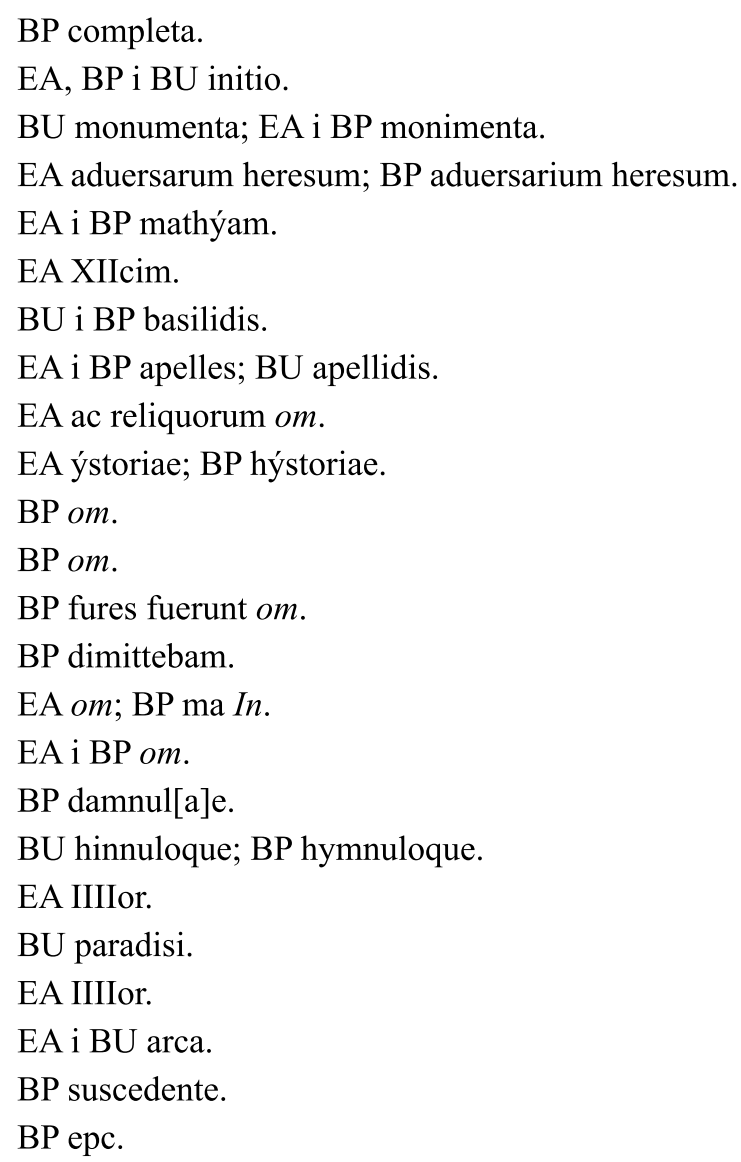


$\mathrm{d}[\mathrm{omi}] \mathrm{n}[\mathrm{u}] \mathrm{m}$ quide[m] ${ }^{66}$ saluatorem ipse n[on] uidit s[ed] ea qu[a]e magistru[m] audierat p[rae] dicante $[\mathrm{m}]$ iuxta fide $[\mathrm{m}]$ magis gestor[um] narrauit qua[m] ordinem. Tercius ${ }^{97}$ Lucas medicus natione sýrus antiocensis ${ }^{98}$ cui[us] laus in [a]eu[an]gelio qui et ipse discip[u][ [u]s ap[osto]li pauli in achai[a]e bitini[a]eq[uae] ${ }^{99}$ partib[us] uolumen c[on]didit queda[m] altius repetens et ut ipse in $\mathrm{p}[\mathrm{re}] \mathrm{hmio}^{\mathrm{ro}}$ confitet[ur] audita magis qua[m] uisa describens. Vultimus ioh[anne]s ap[osto]l[u]s et [a]eu[an]g[e]lista que[m] ihs ${ }^{\text {Ior }}$ amauit plurimu[m] q[ui] sup[er] pectus d[omi]ni recumbens purissima doctrinar[um] fluenta potauit et qui solus de cruce meruit audire: ecce mater tua $\left(\mathrm{J}\right.$ 19,27). Is cum esset in asia ${ }^{102}$ et iam $^{103}$ tunc hereticor[um] ${ }^{104}$ semina pullularent cerenthi hebionis ${ }^{105}$ et c[a]eterror[um] qui negant $\mathrm{xpm}$ in carne uenisse quos et ipse in [a] ep[istu]la sua antichristos ${ }^{106}$ uocat et ap[osto][[u]s paulus frequent[er] p[er]cutit coactus est ab om[n]ib[us] pene tunc asi[a] $\mathrm{e}^{107} \mathrm{ep}[\mathrm{iscop}]$ is et multar[um] [a]eccl[esia]ru[m] legationib[us] $\mathrm{de}^{\mathrm{i08}}$ diuinitate saluatoris altius scribere et ad ipsum ut ita dicam dei uerbu[m] non tam audaci qua $[\mathrm{m}]$ felici temeritate $\mathrm{p}[\mathrm{ro}] \mathrm{rump}[\mathrm{er}] \mathrm{e}$. ut [a]eccl[esi]astica narrat historia ${ }^{\text {109 }}$ cum a fr[atr] $\mathrm{ib}$ [us] cogeret[ur] ut scriberet, ita facturu[m] $]^{\mathrm{IO}}$ respondisse, si indicto ieiunio incommune om[ne $] \mathrm{s} \mathrm{d}[\mathrm{eu}] \mathrm{m}$ precarentur ${ }^{\mathrm{III}}$. Quo expleto reuelatione saturatus in illud $\mathrm{p}[\mathrm{re}] \mathrm{hmium}^{\mathrm{II} 2} \mathrm{c}[\mathrm{a}]$ elo ueniens eructauit: In p[ri]ncipio erat uerbum et uerbum erat apud d[eu]m et d[eu]s erat uerbum, hoc erat in p[ri]ncipio ap [u]d d[eu]m. $\mathrm{H}[\mathrm{ae}] \mathrm{c}$ ig[itur] quattuor [a]eu[an]g[e]lia multo ante $\mathrm{p}$ [re]dicta ezechielis ${ }^{13}$ quoq[ue] uolumen $\mathrm{p}$ [ro]bat, in quo $\mathrm{p}$ [ri]ma uisio ita contexit[ur]: et in medio sicut similitudo quattuor ${ }^{\mathrm{II} 4}$ animaliu[m] et uult[us] eor[um] facies hominis et facies leonis et facies uituli et facies aquil[a]e. Prima hominis facies matheu[m] significat q[ui] quasi de homine exorsus est scribere: liber generationis ih [esu] x [pi] ${ }^{115}$, filii dauid, filii Abraham. $\mathrm{S}[\mathrm{e}] \mathrm{c}[\mathrm{un}] \mathrm{da}$ marcum in quo uox leonis in heremo rugientis audit[ur]: uox clamantis in deserto, parate uiam d[omi]nin ${ }^{\mathrm{I1}}$ rectas facite seminas ${ }^{\mathrm{II7}}$ ei [us]. Tercia ${ }^{\mathrm{II}}$ uituli qu[a]e [a]eu[an]

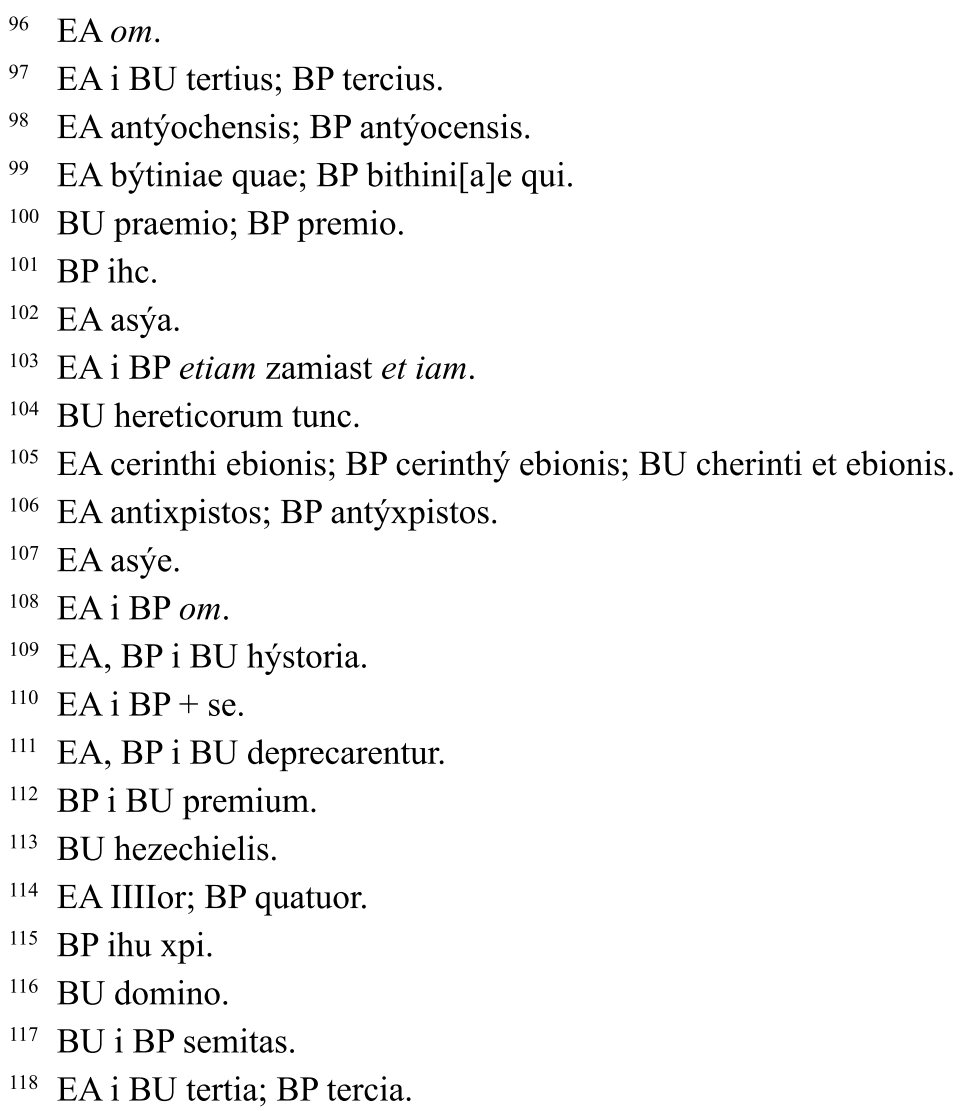


$\mathrm{g}[\mathrm{e}]$ listam lucam $\mathrm{a}^{\text {II9 }}$ zacharia sacerdote $\mathrm{su}[\mathrm{m}] \mathrm{psisse}$ inicium ${ }^{\text {I20 }}$ prefigurat. Quarta ioh[ann] em [a]eu[an]g[e]listam qui asu[m]ptis ${ }^{121}$ pennis aquil[a]e et ad altiora festinans de uerbo d[e] i disputat. C[a]etera qu[a]e sequunt[ur] ${ }^{122}$ in eundem sensum p[ro]ficiunt. Crura eor[um] recta et pennati pedes et quocu[m]q[ue] spc ibat, ibant et ${ }^{123} \mathrm{n}$ [on] reuertebant[ur] et dorsa eor[um] plena oculis et scintill[a]e ac lampades in medio discurrentes et rota in rotam et in singulis quattuor $^{124}$ fecies. Vnde et apocalýpsis ${ }^{125}$ ioh[ann]is post ex positione[m] uiginti quattuor ${ }^{126}$ senior[um] qui tenentes cýtharas et fialas ${ }^{127}$ et adorant agnum dei introducit fulgura et tonitura et septe $[\mathrm{m}] \mathrm{spc}$ descurrentes ${ }^{128}$ et mare uitreum et $\mathrm{q}[$ uat $]$ tuor $^{129}$ animalia plena oculis dicens: Animal p[rim]um simile leoni et s[e]c[un]d[u]m simile uitulo et terciu[m] ${ }^{130}$ simile homini ${ }^{13 \mathrm{~T}}$ et quartu[m] simile aquil[a]e uolanti. Et post paululum: Plena, inquit, erant oculis et requiem $n[o n]$ hababant die ac nocte dicentia: $s[a n] c[t u] s, s[a n] c[t u] s, s[a n] c[t u] s d[o m i] n[u] s d[e u] s$ om[ni]p[oten]s qui erat et qui est et qui uenturus est (Ap 4,7-8). Quib[us] cunctis $\mathrm{p}[\mathrm{er}] \mathrm{spicue}$ ostenditur quattuor ${ }^{132} \operatorname{tantu}[\mathrm{m}]$ debere $^{133}[\mathrm{a}] \mathrm{eu}[\mathrm{an}] \mathrm{g}[\mathrm{e}] \mathrm{lia}$ suscipi ${ }^{\mathrm{1} 34}$ et om[ne]s apocriforum ${ }^{135}$ nenias $^{136}$ mortuis magis hereticis qua[m] [a]eccl[esi] asticis uiuis ${ }^{137}$ canendas $^{138}$.

IHERONYM[US] DAMASO PAP[AE] ${ }^{139}$. Tekstu nie ma w Biblii Ptockiej i Ewangeliarzu Anastazji.

\section{INCIPIT ARGUMENTU[M] S[E]C[UN]D[U]M MATHEU[M] $]^{140}$}

MATHEUS ex iudea sicut in ordine prim[us] ponit[ur] ita [ae]u[an]gel[iu]m in iudea prim[us] scripsit ${ }^{141}$. Cui[us] uocatio ad d[ominu]n ex publican[is] actib[us] fuit. Duor[um] in

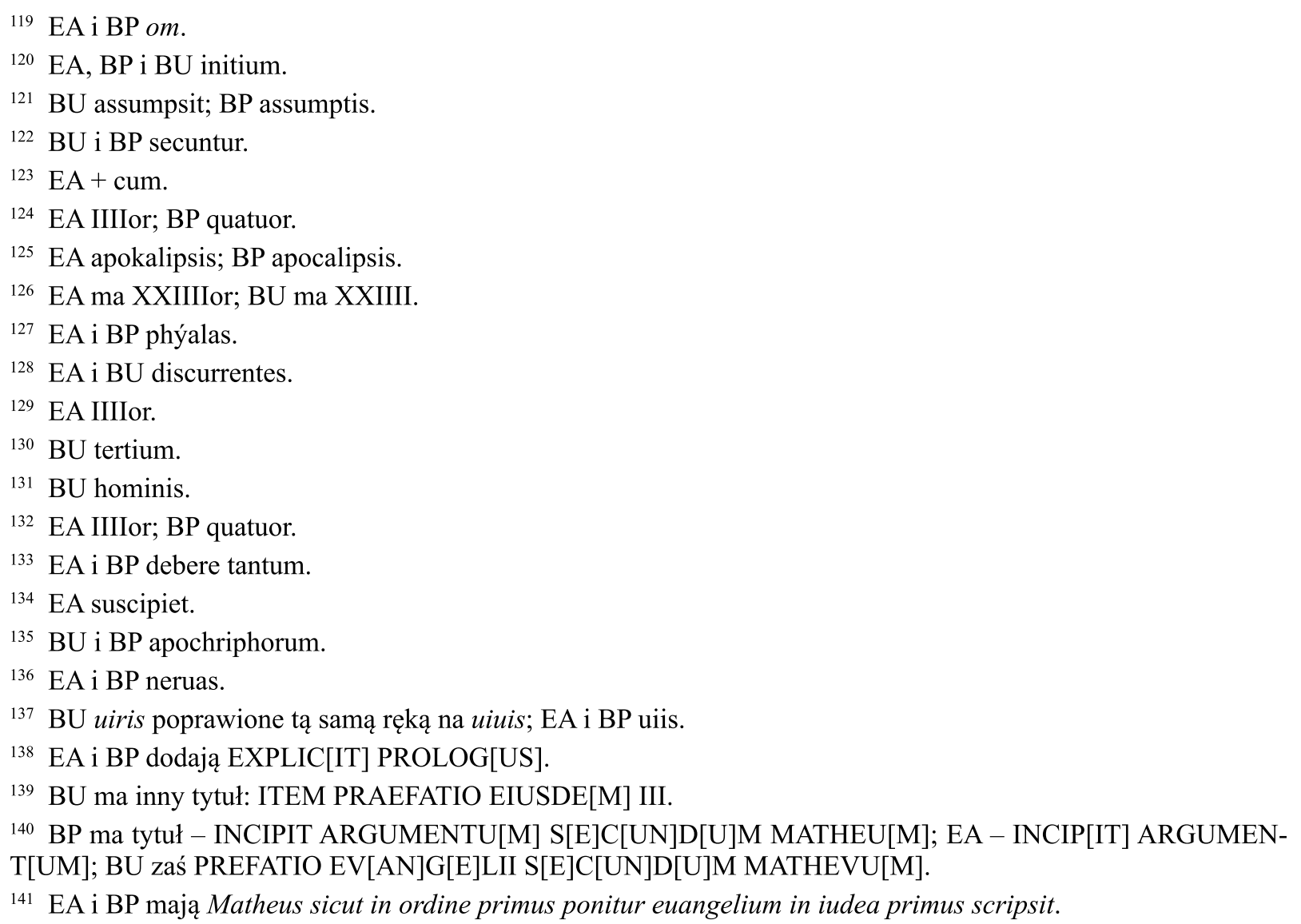


generatione xpi $\mathrm{p}[\mathrm{ri}] \mathrm{ncipia} \mathrm{p}[\mathrm{re}]$ sumens, unius cuius $\mathrm{p}[\mathrm{ri}] \mathrm{ma}$ circu[m]cisio in carne $\mathrm{e}^{\mathrm{T4} 2}$, alterius cui[us] s[e]c[un]d[u]m cor electio fuit ex utrisq[ue] ei[us] ${ }^{143}$ patrib[us] ${ }^{144} \mathrm{xpc}$ sicq[ue] quarter ${ }^{145}$ denario numero trisformiter posito $\mathrm{p}$ [ri]ncipium a credendi fide in electionis temp[us] porrigens et $\mathrm{ex}^{146}$ electione $^{\mathrm{r} 47}$ usq[ue] ${ }^{148}$ in transmigrationis diem dirigens atq[ue] $\mathrm{t}$ [ra]nsmigratio[n]

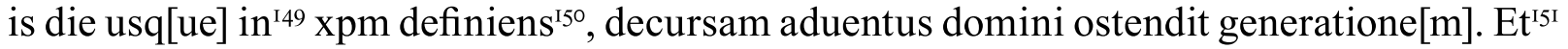
numero satisfacciens $\mathrm{s}^{152}$ et tempori et se q[uo]d esset ostenderet et dei in se opus ${ }^{153}$ monstrans, etia[m] $]^{154}$ in his quor[um] genus posuit xpi operantis a p[ri] ncipio testomoniu[m] non negaret. Quar[um] omniu[m] reru[m] temp[us], ordo numer[us] disposito uel ratio q[uo]d fidei necessariu[m] est, d[ominu]s xpc est qui factus est ex muliere factus sub lege, natus ex virgine, passus in carne, om[n]ia in cruce fixit ${ }^{155}$ ut triumphans ea in semetipso, resurgens in corpore et patris ${ }^{156}$ nomen in patrib[us] filio et filíi ${ }^{157}$ nom[en] patri restituens in filíí158 ${ }^{158}$, sine principio, sine fine, ostendens unum se cu[m] patrem esse, quia unus est ${ }^{159}$. In quo [a]eu[an]gelio utile est $^{160}$ desiderantib[us] d[ominu]m sic p[ri]ma uel media ${ }^{161}$ uel $^{162} \mathrm{p}$ [er]fecta cognoscere ut et uocatione $[\mathrm{m}]^{163}$ ap[osto]li et opus [a]eu[an]gelíi et dilectione[m] dei in carne nascentis p[ro] uniuersa legentes intelligant atq[ue] $\mathrm{id}^{164}$ in eo in quo app[re]hensi sunt et app[re]hendere expetunt, recognoscant. Nobis eni[m] hoc in ${ }^{165}$ studio argum[en]ti fuit et fidem fact[a]e rei traderE et operantis d[omin]i intelligendam diligenter esse ${ }^{166}$ dispositone[m] querentib[us] non tacere.

\section{EXPLICIT ARGUMENTUM ${ }^{167}$}

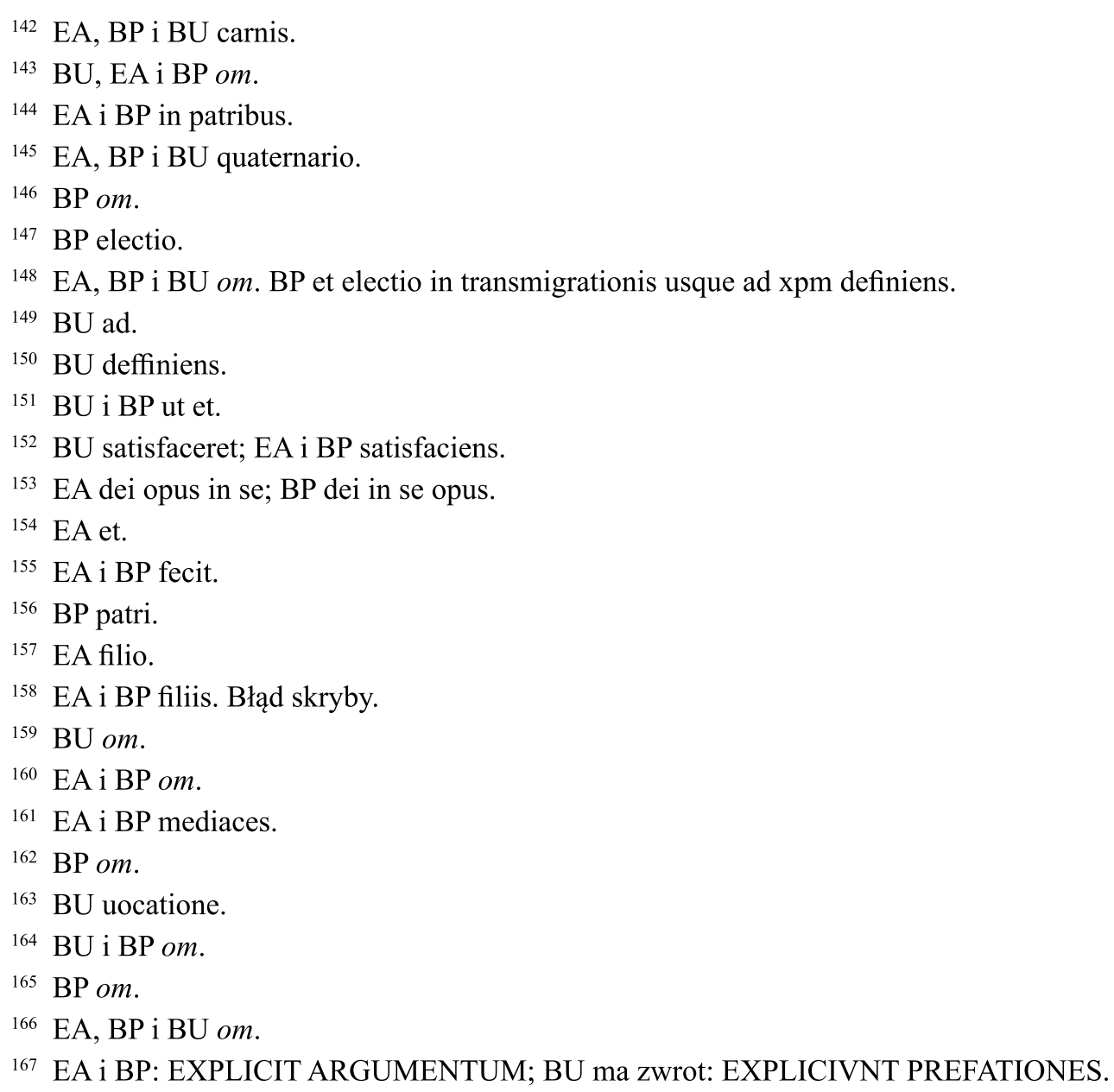




\section{INCIPIT PROLOG[US] IN MARCO ${ }^{168}$}

MARCUS EVANgelista d[ei ${ }^{169}$ et petri in baptismate filius atq[ue] in diuino sermone discipulus, sacerodcium ${ }^{170}$ in ih[er]usal[e]m ${ }^{171}$ agens, $\mathrm{s}[\mathrm{e}] \mathrm{c}[\mathrm{un}] \mathrm{d}[\mathrm{u}] \mathrm{m}$ carnem leuita, conuersus ad fidem xpi ${ }^{172}$, [a]eu[an]g[e]1[iu]m in italia sc[ri]psit, ostendens in eo quid et generi suo deberet et xpo. Nam iniciu[m] $]^{173}$ principis $^{174}$ in uoce $\mathrm{p}[\mathrm{ro}]$ phetic[a]e exclamationis instituens ordinem leuitic[a]e electionis ostendit ut $\mathrm{p}[\mathrm{re}] \mathrm{dicans}^{175} \mathrm{p}[\mathrm{re}]$ destinatum ${ }^{176}$ iohanne $[\mathrm{m}]$ filiu[m] zachari[ae $]^{177}$ in uoce angeli annuciantis ${ }^{178}$ emissum $^{179}$ non solum uerbum caro ${ }^{180}$ factum $\mathrm{s}[\mathrm{ed}]$ corpus d[omi]ni in omnia ${ }^{181}$ per uerbum diuin[a]e uocis animatum inicio ${ }^{182}[\mathrm{a}] \mathrm{eu}[\mathrm{an}] \mathrm{g}[\mathrm{e}]$ lic[ae] p[re]dicationis ostenderet ut qui h[a]ec legens sciret cui inicium ${ }^{183}$ carnis in d[omi]no et ihu ${ }^{184}$ aduenientis habitaculum caro debere ${ }^{185}$ agnoscere, atq[ue] in se uerbum uocis quod in consonantib[us $]^{186} \mathrm{p}[\mathrm{er}]$ diderat inueniret. Deniq[ue] et ${ }^{187} \mathrm{p}[\mathrm{er}] \mathrm{fecti}[\mathrm{a}] \mathrm{eu}[\mathrm{an}] \mathrm{g}[\mathrm{e}]$ líi intrasset opus $^{188}$ a baptismo domini $\mathrm{p}[\mathrm{re}]$ dicare $\mathrm{d}[\mathrm{ominu}] \mathrm{m}$ inchoans ${ }^{\mathrm{r} 8}$, non laborauit natiuitate[m] carnis quia in priorib[us] uiderat dicere $\mathrm{s}[\mathrm{ed}]$ totu $\mathrm{s}^{190}$ in exprimen $\mathrm{s}^{19 \mathrm{I}}$ expositionem deserti ieiunium numeri, temptation $[\mathrm{m}]$ diaboli congregatione $[\mathrm{m}]$ bestiaru[m] et ministeri[um] $\mathrm{p}[\mathrm{ro}]$ tulit angelor[um] ut ${ }^{192}$ instituens nos ad intelligendu[m] singula in breuis ${ }^{193}$ compingens ${ }^{194}$ nec

${ }^{168}$ BU ma zwrot: INCIPIT PROLOG[US] S[E]C[UN]D[U]M MARUM; BP ma tytuł; INCIP[IT] PROLOG[US] IN EV[AN]GELIO S[ECUNDU]M MARCV[M]; EA nie zawiera Ewangelii Marka.

${ }^{169} \mathrm{BP}+$ elect[us].

${ }^{170}$ Ewangelia Marka (=EM), BP i BU sacerdotium.

171 BU om.

172 EM ad fidem xpi conuersus.

${ }^{173}$ EM, BP i BU initium; BP initium + euangelii.

174 EM, BP i BU principíi.

${ }^{175} \mathrm{BP}+$ ioh[anne]m.

176 BU i BP predestinatum.

177 BP predicans ioh[anne]m predestinatum filium zachari[a]e.

178 BU adnuntiantis.

${ }^{179} \mathrm{EM}$ emissum anuntiantis.

${ }^{180} \mathrm{BP}$ carnem.

${ }^{181} \mathrm{BP}$ om in omnia.

${ }^{182}$ EM, BP i BU initio.

${ }^{183} \mathrm{EM}, \mathrm{BP}$ i BU initium.

${ }^{184} \mathrm{BP}$ in ihu.

${ }^{185}$ BP debere.

${ }^{186}$ BP consumationibus.

${ }^{187}$ EM cum zamiast et; BU i BP om.

${ }^{188} \mathrm{EM}, \mathrm{BP}$ i BU opus intrasset.

189 EM incipiens.

${ }^{190}$ EM totius.

${ }^{191} \mathrm{BU}$ i BP in primis.

${ }^{192}$ BU om.

${ }^{193} \mathrm{BP}$ singula[m] breui.

${ }^{194}$ BU conpingens. 
auctoritate $[\mathrm{m}]$ fact $[\mathrm{a}] \mathrm{e}^{195}$ rei demerit ${ }^{196} \mathrm{et} \mathrm{p}[\mathrm{ro}]$ ficiendi operis ${ }^{197}$ plenitudine $[\mathrm{m}]$ non negaret. Deniq[ue] amputasse ${ }^{198}$ sibi post fidem pollicem dicit[ur] ${ }^{199}$ ut sacerdocio ${ }^{200}$ reprob[us] habere$\mathrm{t}[\mathrm{ur}]$. S[ed] tantu[m] consenciens ${ }^{201}$ fidei p[re]destinata potuit electio ut nec sic op[er] $\mathrm{e}^{202}$ uerbi $\mathrm{p}$ [er]deret $\mathrm{q}[\mathrm{uo}] \mathrm{d}$ pri[us] meruerat in genere. Nam alexandri[a]e epc ${ }^{203}$ fuit cuius $\mathrm{p}[\mathrm{er}]$ singula opus scire et [a]eu[an]g[e]lií in se dicta disponere et disciplinam in se legis agnoscere ${ }^{204}$ et diuina $[\mathrm{m}]$ in carne ${ }^{205} \mathrm{~d}[\mathrm{omi}] \mathrm{ni}^{206}$ intelligere natura[m] qu[a]e in nos primu[m] require ${ }^{207}$, de hinc inquisita uolumus agnosci habentes mercede[m] exhortationis q[ue]m qui plantat et qui rigat unum sunt, qui au[tem] incrementum prestat devs EST.

\section{EXPLICIT ARGUMENTUM ${ }^{208}$}

\section{Bez tytułu ${ }^{209}$}

LUCA SÝRUS antiocensis ${ }^{210}$, arte medicus, discipul[us] ap[osto]lor[um], post ${ }^{211}$ paulum secutus usq[ue] ad confessionem ${ }^{212}$ eius seruiens d[omin]o sine crimine. Nam neq[ue] uxorem umqua [m] habens neq[ue] filios, septuaginta et quattuor ${ }^{213}$ annor[um] obíit in bithinia ${ }^{214}$ plenus $\mathrm{sp}[$ irit $] \mathrm{u} \mathrm{s}[\mathrm{an}] \mathrm{c}[\mathrm{t}] \mathrm{o}$. Qui cum iam scripta essent $[\mathrm{a}] \mathrm{eu}[\mathrm{an}] \mathrm{g}[\mathrm{e}] \mathrm{lia}$ per matheum quidem in iudea, $\mathrm{p}[\mathrm{er}] \operatorname{marcu}[\mathrm{m}]$ aute[m] in italia, $\mathrm{s}[\mathrm{an}] \mathrm{c}[\mathrm{t}] \mathrm{o}^{215}$ instigante $\mathrm{sp}[$ irit $] \mathrm{u}$ in achai[a] $\mathrm{e}^{216}$ partib[us] hoc $\mathrm{sc}[\mathrm{ri}] \mathrm{psit}[\mathrm{a}] \mathrm{eu}[\mathrm{an}] \mathrm{g}[\mathrm{e}] \mathrm{liu}[\mathrm{m}]$ significans etia[m] ipse in principio ante alia e[ss]e descripta. Cui

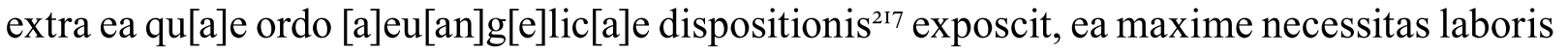
fuit ut primu[m] grecis fidelib[us] om[n]i p[ro]phetatione uenturi ${ }^{218}$ in carne[m] d[omi]nni ${ }^{219} \mathrm{xpi}$

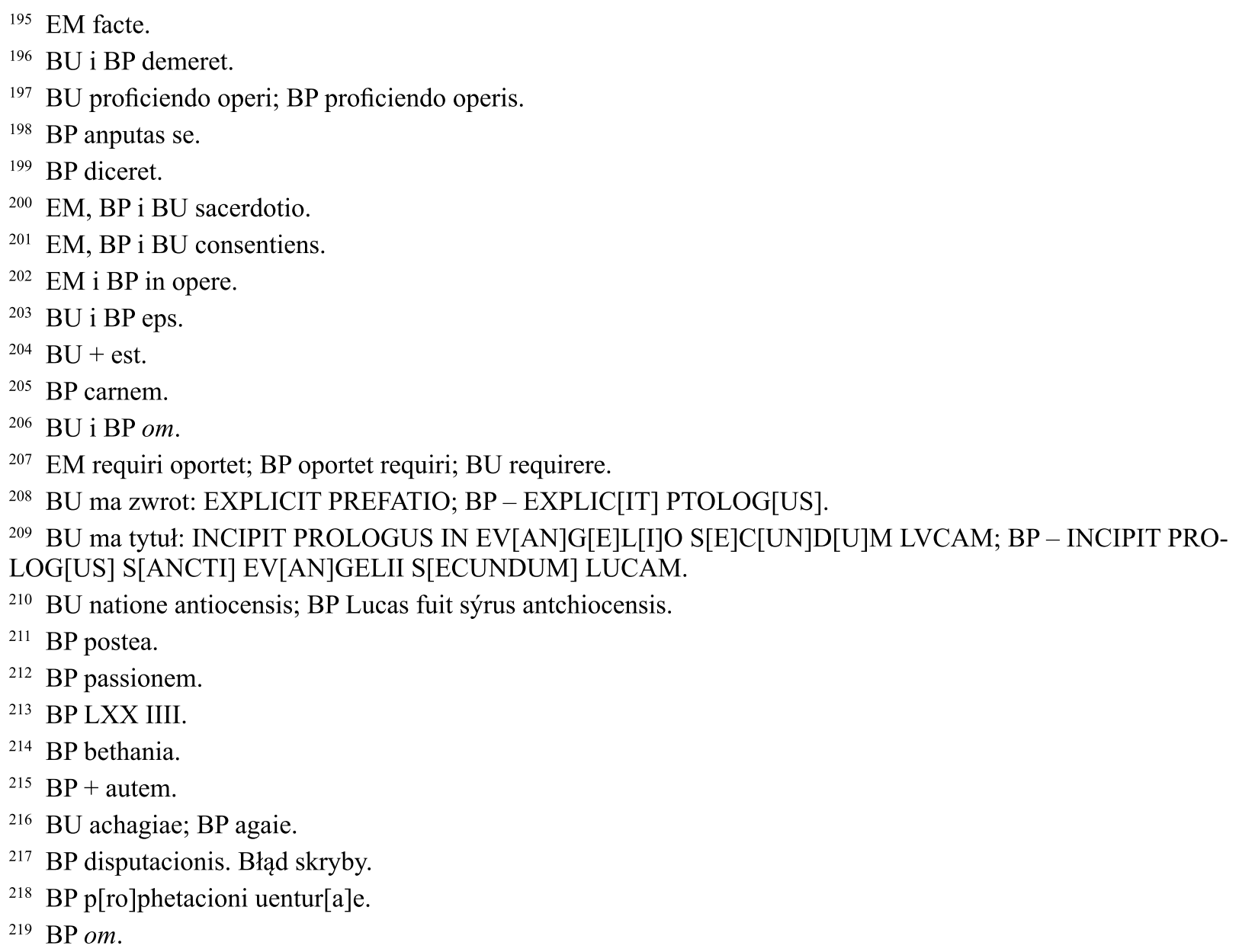


manifesta ${ }^{220}$ humanitas ne iudaicis ${ }^{221}$ fabulis attenti ${ }^{222}$ in solo legis desiderio tenerent[ur] ne $\mathrm{uel}^{223}$ hereticis fabulis et stultis sollicitationib[us] seducti excederent a ueritate elaboraret. De $h_{i n c}{ }^{224} u t$ in principio [a]eu[an]g[e]líi ioh[ann]is natiuitate presu[m]pta cui [a]eu[an]g[e]l[iu]m scriberet et in quo electus scriberet indicaret contestans in se complete $\left.{ }^{225} \mathrm{e}[\mathrm{ss}] \mathrm{e} \mathrm{qu} \mathrm{a}\right] \mathrm{e}$ essent $\mathrm{ab}$ alíís inchoata. Cui ideo ${ }^{226}$ post baptismum filíís dei a $\mathrm{p}$ [er]fectione generationis in xpo implet[a] $\mathrm{e}^{227}$ repetend[a]e a $\mathrm{p}$ [ri]ncipio natiuitatis human[a]e potestas $\mathrm{p}$ [ro]missa est ut req[ui] rentib[us] demonstraret in quo app[re]henden $\mathrm{s}^{228}$ erat $\mathrm{p}$ [er] nathan filium introitum recurrentis in $\mathrm{d}[\mathrm{ominu}] \mathrm{m}^{229}$ generationis $^{230}$ ammisso $^{231}$ indisparabilis dei $\mathrm{p}$ [re]dicans in hominib[us] xpm $\mathrm{suu}[\mathrm{m}] \mathrm{p}$ [er]fecti opus hominis redire in $\mathrm{se}^{232} \mathrm{p}$ [er] filium faceret qui $\mathrm{p}$ [er] dauid patre[m] uenientib[us] iter $\mathrm{p}[\mathrm{re}] \mathrm{dicabat}^{233}$ in xpo. Cui luc[ae] non immerito ${ }^{234}$ etia[m] scribendor[um] apostolicor[um] actuum ${ }^{235}$ potestas in mýsterio ${ }^{236}$ datur ut deo in $\mathrm{d}[\mathrm{eu}] \mathrm{m}$ pleno et filio $\mathrm{p}[\mathrm{re}]$ dicionis $^{237}$ extincto oratione $\mathrm{ab}$ ap[osto]lis facta forte $\mathrm{d}$ [omi]ni electionis $\mathrm{s}^{238}$ numerus co[m] pleretur. Sicq[ue] Paulus consummation[m] ap[osto]licis actib[us] daret que[m] diu stimulum recalcitrante[m] $]^{239} \mathrm{~d}[\mathrm{omi}] \mathrm{n}[\mathrm{u}] \mathrm{s}$ elegisset. Quod et legentib[us] ac requirentibus d[ominu] $\mathrm{m}^{240}$ et si $\mathrm{p}$ [er] singula expediri a nobis ${ }^{24 \mathrm{I}}$ utile fuerat sciens tamq[uam] ${ }^{242} \mathrm{q}[\mathrm{uo}] \mathrm{d}$ operantem agricolam oporteat de fructib[us] suis edere uitauimus publicam curiositate[m] ne non tam uolenitb[us] d[ominu] $\mathrm{m}^{243}$ uideremur quam fastidientibus PRODESSE ${ }^{244}$.

\section{EXPLCIT ARGUMENTU[M] SECUNDUM LUCAM ${ }^{245}$}

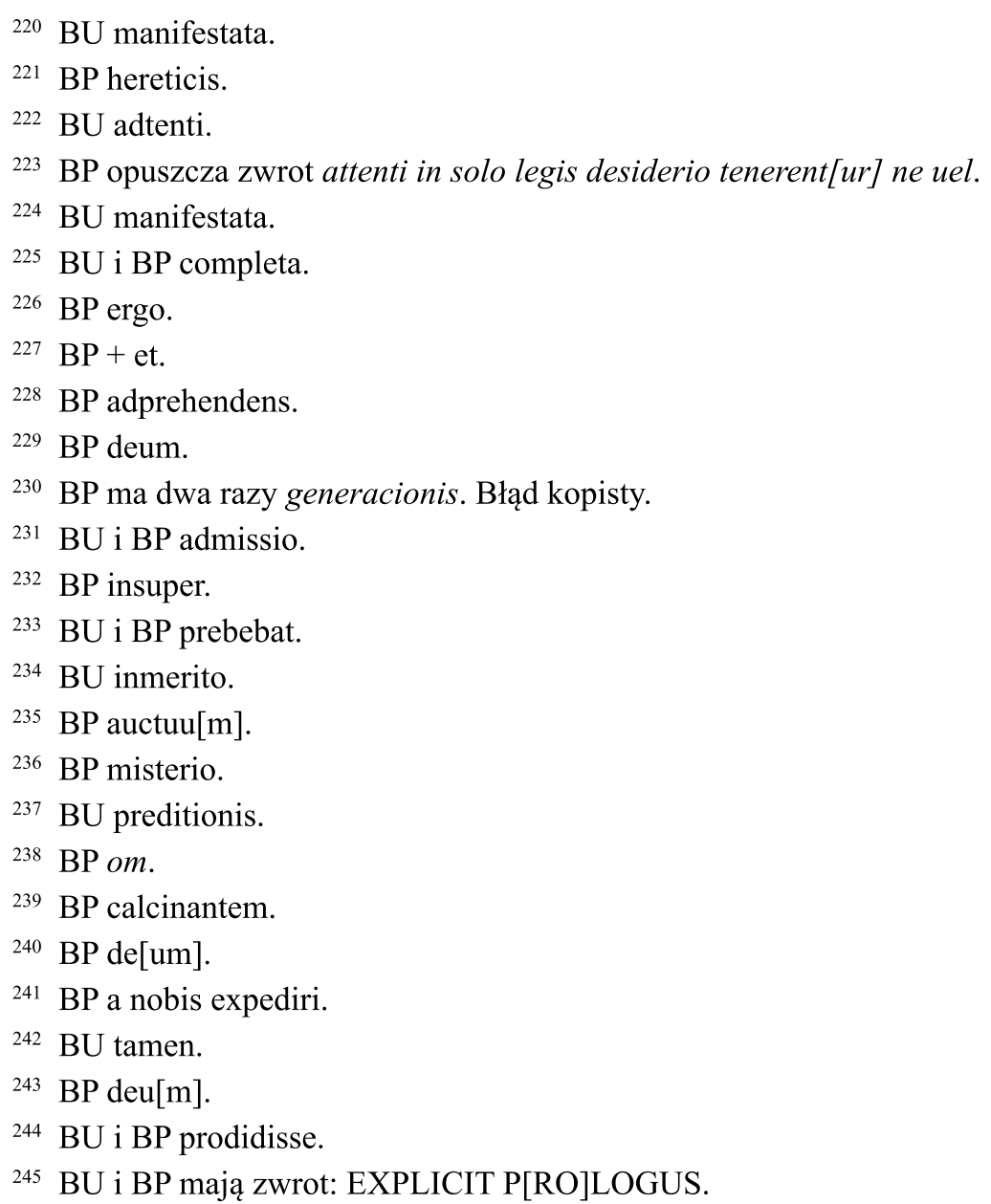




\section{INCIPIT PROLOGUS SEC[UN]D[U]M IOHANNEM ${ }^{246}$}

HIC EST IOH[ANNE]S [a]eu[an]g[e]lista unus ex discipulis dei ${ }^{247}$ qui uirgo electus est a deo ${ }^{248}$, que[m] de nuptíís uolentem nubere uocauit deus ${ }^{249}$. Cui $^{250}$ uirginitatis $^{251}$ in hoc duplex testimonium in [a]eu[an]g[e]lio datur ${ }^{252}$ quod a pr[a]e c c[a]eteris dilectus a d[omin]o dicit[ur] et huic matre $[\mathrm{m}]$ suam de cruce ${ }^{253} \mathrm{co}[\mathrm{m}]$ mendauit d[omi[n]u[s] ut uirgo uirgine $[\mathrm{m}]^{254}$ seruaret. Deniq[ue] manifestans in [a]eu[an]g[e]lio quod erat ipse incorruptibilis uerbi opus inchoans solus uerbum carne $[\mathrm{m}]^{255}$ factu[m] esse nec lumen a tenebris comp[re] hensu[m] ${ }^{256}$ fuisse testat[ur]. Primu[m] signu[m] ponens q[uo]d in nuptíís fecit d[omi]n[u]s ut ${ }^{257}$ ostendens q[uo]d erat ipse ${ }^{258}$ legentib[us] demonstraret quod ubi d[omi]n[u]s inuitatus deficere nuptiar[um] ${ }^{259}$ uinu[m] debeat ut et ${ }^{260}$ ueterib[us] immutatis noua ${ }^{261} \mathrm{om}[\mathrm{n}] \mathrm{ia}$ qu[a]e a xpo instituunt[ur] appareant. Hoc aute[m] [a]eu[an]g[e]1[iu]m scripsit in asia postea qua[m $]^{262}$ in pathmos insula apocalýp $\sin ^{263}$ scripserat ut cui in $\mathrm{p}$ [ri]ncipio canonis incorruptibile $\mathrm{p}$ [ri]ncipium in genesi etia[m] incorruptibilis finis $\mathrm{p}[\mathrm{er}]$ uirginem in apocalýpsi ${ }^{264}$ redderet[ur] dicente xpo: ego sum A et $W$. Et hic est ioh[anni]s qui sciens sup[er]uenisse diem recessus sui conuocatis discipulis suis in epheso $\mathrm{p}$ [er] multa signor[um] experimenta promens xpm descendens in defossum sepulture[a]e su[a]e locu[m] facta oratione ${ }^{265}$ positus est ad patres suos tam ex traneus ${ }^{266}$ a dolore mortis qua[m] a corruptione carnis inuenit[ur] alienus. Tamen post om[ni] $\mathrm{s}^{267}[\mathrm{a}]$ $\mathrm{eu}[\mathrm{an}] \mathrm{g}[\mathrm{e}][\mathrm{iu}] \mathrm{m}$ scripsit et hoc uirgini debebat[ur ${ }^{268}$. Quor[um] tam[en] uel scriptor[um] temp[or]e dispositio uel libror[um] ordination ideo $\mathrm{p}[\mathrm{er}]$ singula nobis ${ }^{269}$ non exponit[ur] ut

\footnotetext{
${ }^{246}$ BP ma tytuł: INCIP[IT] P[REP]H[ATI]O IN EV[AN]GELIO S[ECUNDUM] IOHANNE[M]; w EA brak jakiegokolwiek tytułu; BU ma zwrot: P[RE]F[ATIO] EV[AN]G[E]LII S[E]C[UN]D[U]M IOHANNEM.

${ }^{247}$ EA i BP domini.

${ }^{248}$ BU i BP a Deo est.

249 EA i BP dominus.

${ }^{250} \mathrm{BU}$ i BP cuius.

${ }^{251}$ BP uirginitati.

${ }^{252} \mathrm{BP}$ dat[ur] in euang[e]lio.

${ }^{253} \mathrm{EA} * * *$ iens de cruce; BU i BP pendens in cruce.

${ }^{254}$ EA i BP uirginem uirgo.

${ }^{255}$ EA, BP i BU caro.

${ }^{256} \mathrm{BU}$ conprehensum.

${ }^{257} \mathrm{BP}$ om.

${ }^{258}$ EA, BP i BU ipse erat.

259 BP nupciarum.

${ }^{260}$ BP ma ac zamiast ut et.

${ }^{261}$ BP nouo.

${ }^{262}$ BU postquam.

${ }^{263}$ EA apokalipsin; BP apocalipsim.

${ }^{264}$ EA apokalipsi; BP apocalipsi; BU apocalýpsin.

${ }^{265}$ BP oracione.

${ }^{266}$ EA, BP i BU extraneus.

${ }^{267} \mathrm{BP}$ om[n]es.

${ }^{268}$ BP debetur.

${ }^{269}$ EA, BP i BU a nobis.
} 
scienti $^{270}$ desiderio collocetur ${ }^{271}$ et qu[a]erentib[us] fructus laboris et deo magisteríí doctrina seruetur. AMEN ${ }^{272}$.

\section{EXPLICIT PROLOGUS S[E]C[UN]D[U]M IOHANNEM. ${ }^{273}$}

Zanim przedstawię kilka wniosków, które nasuwają się po porównaniu wspomnianych tekstów, zacznijmy od uwagi bardziej ogólnej dotyczącej autorstwa tych tekstów. Pierwsze trzy teksty, czyli Beatissmo pape Damaso (Novum opus), Prologus quatuor evangeliorum (Plures fuisse) i Iheronimus Damaso pape (Sciendum etiam), którego nie ma w Biblii Ptockiej i Ewangeliarzu Anastazji są autorstwa św. Hieronima. Natomiast wprowadzenia do Ewangelii synoptycznych: Argumentum secundum Matheum, Prologus in Marco i Prologus sancti Evangelii secundum Lucam nie są autorstwa św. Hieronima, jak to niekiedy błędnie powtarzają badacze albo tzw. Dialogami monarchiańskimi, bo taka nazwa również funkcjonuje w obiegu naukowym, ale są autorstwa Seduliusza Szkota, mnicha i poety irlandzkiego, który żył i tworzył w szkole w Leodium w IX w. ${ }^{274}$, zaś wprowadzenie do Ewangelii Janowej Prephatio in Evangelium secundum Iohannem jest autorstwa Bedy Czcigodnego ${ }^{275}$. To ustalenie jest bardzo ważne, gdyż często wszystkie te teksty błędnie przypisywano św. Hieronimowi. O ile teksty Hieronima były dosyć powszechnie używane w biblijnych kodeksach średniowiecznych w całej ówczesnej Europie, o tyle fakt, że wprowadzenia do Ewangelii synoptycznych są autorstwa Seduliusza i są obecne zarówno w Biblii Płockiej jak też częściowo w Ewangeliarzu Anastazji, jest bardzo mocnym argumentem za leodyjskim pochodzeniem biblijnych kodeksów płockich z XII w. Co oczywiście nie oznacza jeszcze, że musiały powstać nad Mozą i zostały przywiezione do Płocka, bo równie dobrze mogły zostać przepisane na miejscu przez kopistów z Leodium. Dalej, widzimy, że tak samo pisano w kodeksach płockich i leodyjskich, prawdopodobnie ze względu na wymowę imię Hieronima: Iheronimus. Analiza zaś porównawcza samych tekstów wyraźnie prowadzi do kilku ważnych wniosków. Po pierwsze, Biblia Płocka, a za nią Ewangeliarz Anastazji, są bliższe wersji tekstu zachowanej w Biblia Universa, kodeksie pochodzącym z klasztoru sancti Trudonis niż w Ewangeliarzu z Averbode. Oczywiście nie są to jakieś ogromne różnice, ale te same elementy różnicujące powtarzają się w tych trzech kodeksach. $Z$ tego wynika, że źródeł dla biblijnych kodeksów płockich z XII w. trzeba szukać w leodyjskich klasztorach benedyktyńskich, być może w samym klasztorze sancti Trudonis niedaleko Liège. Po drugie, kodeks płocki zwierający Ewangelię Marka dosyć często, choć nie zawsze, idzie za wersją tekstu zachowaną w Biblii Płockiej i Biblia Universa. Wypada więc mieć nadzieje, że dalsze badania porównawcze, zwłaszcza wersji samego tekstu biblijnego, potwierdzą tę zależność i pomogą ustalić czy kodeks powstał nad Mozą czy może jest odpisem z Biblii Płockiej wykonanym na miejscu. Po trzecie wreszcie, i jest to wniosek niezmiernie interesujący, Ewangeliarz Anastazji, nie licząc drobnych zmian kopisty typu zamiana - tium na - cium

\footnotetext{
270 BP sciendi.

271 EA collocata; BU i BP conlocato.

272 EA, BP i BU om.

${ }^{273}$ BP ma zakończenie: EXPLIC[IT] P[RE]PHATIO; BU - EXPLICIT PRAEFATIO.

274 Por. Patrologia Latina (=PL) 103, 273-274: Argumentum in Mattheum; PL 103, 279-280: Argumentum in Marcum; PL 103,285-286: Argumentum secundum Lucam. Expositiuncula.

275 Por. Patrologia Latina 92,633-636: In Iohannis Evangelium Expositio.
} 
lub pojedynczych liter, jest bardzo mocno zależny od Biblii Płockiej. Najmocniejszym jednak argumentem jest fakt opuszczenia przez obydwa kodeksy w pierwszym tekście Hieronima tej samej frazy: peruersius uel a librariis dormitantibus aut addita sunt aut mutate. Trudno mówić tu o przypadku i powyższy fakt zdaje się wskazywać na to, że Ewangeliarz Anastazji zostałby sporządzony w oparciu o tekst Biblii Płockiej. Jeśli jak potwierdzają zapiski o cudach z II48, Biblia była już w Płocku przed tą datą, to jest bardzo prawdopodobne, że Ewangeliarz Anastazji byłby odpisem tekstu dokonanym na miejscu w Płocku w lokalnym skryptorium jako fundacja Bolesława Kędzierzawego i wotum za zbawienie zmarłej żony Anastazji. Kodeks musiałby zatem powstać po jej śmierci datowanej na II58 r. w Płocku, za czasów już biskupa Wernera i nie zostałby, jak się przypuszcza, przywieziony przez niego podczas jego podróży do Akwizgranu. Natomiast tekst Seduliusza zachowany w Comentaria do Ewangelii Marka odbiega zarówno od Biblii Płockiej jak też Ewangeliarza Anastazji, jest późniejszy i pochodzi najprawdopodobniej z innego środowiska.

Powyższe wnioski są z oczywistych względów jedynie wstępnymi konkluzjami, gdyż porównane teksty nie są zbyt długie i pełniejsze konkluzje będzie można przedstawić dopiero po analizach porównawczych wersji samego tekstu biblijnego czterech Ewangelii.

\section{The Texts of St. Jerome, Sedulius Scottus and Beda Venerable in Plock and Mosan Biblical Manuscripts of XII century Summary}

This article is the comparison of two biblical manuscripts of the twelfth century from Plock, namely the so-called Bible of Plock and Evangeliar of Princess Anastasia with two Mosan biblical manuscripts: Evangeliar of Averbode and the Biblia Universa transcribed in the same period. The first three texts: Beatissimo Papae Damaso (Novum opus), Prologus quatuor evangeliorum (Plures fuisse) and Iheronimus Damaso Pape (Sciendum etiam) - the last one is not in the Bible of Plock - and Evangeliar of Princess Anastasia are of St. Jerome. In contrast, the introduction to the Synoptic Gospels: Argumentum secundum Matheum, Prologus in Marco and Prologus sancti Evangelii secundum Lucam are not the texts of St. Jerome, as is sometimes mistakenly repeated by different scholars, but belong to Sedulius Scottus, an Irish monk and poet who lived and worked in a school in Leodium in the ninth century, and the introduction to the Gospel of John: Prephatio in Evangelium secundum Iohannem was written by Bede the Venerable. While the texts of Jerome were quite commonly used in biblical medieval manuscripts, the fact that the introductions to the Synoptic Gospels are written by Sedulius Scottus and are present in both the Bible of Plock as well as partially in Evangeliar of Princess Anastasia is a very strong argument for the Mosan origin of the biblical manuscripts of Plock from the twelfth century. Comparative analysis of the texts themselves clearly leads to several important conclusions. First, the Bible of Plock and Evangeliar of Princess Anastasia are closer to the version of the text preserved in the Biblia Universa, a codex written in the monastery of Sancti Trudonis, than to Evangeliar of Averbode. It follows that the sources for the biblical manuscripts of Plock from the twelfth century should be searched in Mosan Benedictine monasteries, perhaps in the monastery Sancti Trudonis near Liège. Second, the Gospel of Mark generally follows the version of the text preserved in the Biblia Universa and the Bible of Plock but not all the time. It should therefore be hoped that further comparative studies, especially the version of the biblical 
text, would confirm this relationship and will help determine whether the codex was written in the Mosan region or is a copy of the Bible of Plock made on the spot. Thirdly, and this is an extremely interesting proposal, Evangeliar of Princess Anastasia, not counting minor copyist changes like the conversion of - tium to - cium, is very much dependent on the Bible of Plock. If, as it is confirmed by records of the miracles, the Bible was already in Plock in II 48 or before that date, it is very likely that Evangeliar of Princess Anastasia, would be a copy of the text made on the spot in a local Plock scriptorium as a foundation of Boleslaw Kedzierzawy and a votive offering for the salvation of his deceased wife Anastasia. The codex would therefore arise after her death, dating back to the year II58 in Plock in the time of Bishop Werner and would not have been brought by him following his trip to Aachen.

These conclusions, for obvious reasons, are only preliminary, as comparsion of the texts are not fully detailed and final conclusions will be presented only after benchmarking a version of the biblical text of the four Gospels.

Keywords: biblical codex, medieval Plock, mosan manuscripts

Nota o Autorze: ks. dr hab. Leszek Misiarczyk, prof. UKSW. Pracuje na Wydziale Nauk Historycznych i Społecznych UKSW w Warszawie. 